\title{
Proses Public Relations Kegiatan Open House PT. Dirgantara Indonesia Dalam Membangun Brand Awareness
}

\author{
Firna Grania ${ }^{1}$, Yanti Setianti², dan Heru Ryanto Budiana ${ }^{3}$ \\ ${ }^{1,2,3}$ Universitas Padjadjaran
}

\begin{abstract}
ABSTRAK
Krisis yang dialami PT. Dirgantara Indonesia (PTDI) memengaruhi keberlangsungan perusahaan. Tidak sedikit masyarakat yang mengira bahwa PTDI sudah tidak beroperasi lagi. Masyarakat masih kurang mengetahui mengenai perkembangan yang terjadi dengan PTDI sekarang ini. Baik mengenai perusahaannya, maupun mengenai produk-produk apa saja yang dihasilkan oleh PTDI sendiri. Masyarakat umum hanya mengetahui PTDI secara general saja yaitu, sebuah industri pesawat terbang di Indonesia yang merupakan Badan Usaha Milik Negara. Pada kenyataannya PTDI masih aktif beroperasi dalam bidang aircraft service, engineering service, dan pembuatan komponen-komponen pesawat walaupun belum kembali aktif dalam pembuatan pesawat. Namun dengan kurangnya pengetahuan masyarakat mengenai keberadaan dan perkembangan PTDI yang sekarang, keadaan tersebut menyulitkan PTDI dalam memperkenalkan produk-produknya sehingga PTDI mengadakan kegiatan open house dalam membangun kembali awareness. Tujuan dari penelitian ini adalah untuk mengetahui bagaimana Divisi Humas dan Divisi Protokol PTDI melakukan riset, perencanaan, pelaksanaan, dan evaluasi sebagai panitia pelaksana kegiatan open house dalam membangun kembali awareness masyarakat Bandung terhadap PTDI. Metode yang digunakan dalam penelitian ini adalah metode penelitian deskriptif dengan jenis data kualitatif. Metode pengumpulan data yang digunakan adalah wawancara mendalam, observasi, dan studi pustaka. Hasil dari penelitian ini menunjukkan bahwa Divisi Humas dan Divisi Protokol PTDI melaksanakan kegiatan open house, karena ingin memberikan edukasi mengenai perusahaan Kedirgantaraan sekaligus memperlihatkan keaktifan perusahaan dengan memperkenalkan produk baru N219 kepada masyarakat Bandung. Kesimpulan yang diperoleh dari penelitian ini adalah kegiatan open house tepat dalam membangun kembali brand awareness karena mampu memberikan edukasi baik mengenai industri pembuat pesawat terbang atau PTDI nya sendiri, memperlihatkan bentuk produk secara nyata, dan memperkenalkan aktivitas PTDI kepada masyarakat Bandung. Melalui penelitian ini peneliti menyarankan agar keseluruhan proses mulai dari riset hingga evaluasi dilakukan oleh kedua divisi sebagai panitia pelaksana kegiatan open house atau kedua divisi dapat melakukan konfirmasi terhadap setiap progres perancangan kegiatan.
\end{abstract}

Kata-kata Kunci: PT. dirgantara indonesia; public relations; brand awareness; open house; kegiatan

\section{Public Relations Process On Open House Activities PT. Dirgantara Indonesia In Building Brand Awareness}

\begin{abstract}
The crisis experienced by PT. Dirgantara Indonesia (PTDI) affects the sustainability of the company. Not a few people who think that PTDI is no longer operating. Society is still less aware of the developments that occur with PTDI today. Both about the company, or about what products are produced by PTDI itself. The general public only knows PTDI in general only, that is, an aircraft industry in Indonesia which is a State Owned Enterprise. In fact, PTDI is still actively operating in the field of aircraft service, engineering service, and manufacture of aircraft components although it has not been re-active in making aircraft. But with the lack of public knowledge of the existence and development of PTDI now, the situation makes it difficult for PTDI to introduce its products so that PTDI holds an open house activity in rebuilding awareness. The aim of this study is to learn how the Public Relation and Protocol division of PT Indonesian Aerospace conduct the research, planning, execution, and evaluation as executing committee of open house activity in building Bandung community's awareness of the company. Method used in this study was descriptive method with qualitative data. Data collection methods used were in-depth interviews, observation, and literature study. The results of this study show that the Public Relation and Protocol division of PT Indonesian Aerospace has held the open house activity because they want to give such an education about aerospace company as well as to show the liveliness of the company by introducing its new products N219 to Bandung community. The conclusion of this study is that open house activity is the right choice in building brand awareness because it can give good education about aircraft maker industry or about the company itself, show real forms of its products, and introduce the company's activity to Bandung community. Through this study, the researcher suggests both divisions to conduct the whole process from research to evaluation as executing committee of open house activity, or both divisions can confirm every progress in planning the event
\end{abstract}

Keywords: PT indonesian aerospace, public relations, brand awareness, open house; event

Korespondensi: Dr. Yanti Setianti, M.Si. Universitas Padjadjaran, Jl. Raya Bandung Sumedang km 21. Kode Pos 45365.Email: yantisetianti@gmail.com. 


\section{PENDAHULUAN}

Kredibilitas PT. Dirgantara Indonesia (PTDI) sempat mengalami penurunan selama beberapa tahun semenjak terjadinya krisis pada bulan September tahun 2007. Dimana status PTDI di pailitkan oleh Pengadilan Niaga Jakarta karena permasalahan internal yang terjadi antara perusahaan dengan mantan karyawannya.

Berdasarkan keputusan pengadilan tersebut, maka PTDI dengan terpaksa melakukan penyusutan karyawan karena sejumlah dana yang biasa didapatkan dari pemerintah dikurangi. Namun beberapa karyawan yang merasa kecewa dengan keputusan PTDI yang singkat menuntut melalui jalur hukum. Pada saat itu suasana semakin memanas dengan bertambahnya aksi-aksi demonstrasi yang dilakukan oleh karyawan di depan perusahaan PTDI. Bukan hanya sekali dua kali namun demonstrasi tersebut berlangsung selama bertahun-tahun.

Krisis yang dialami PTDI tersebut memengaruhi keberlangsungan perusahaan. Tidak sedikit masyarakat yang mengira bahwa PTDI sudah tidak beroperasi lagi. Masyarakat masih kurang mengetahui mengenai perkembangan yang terjadi dengan PTDI sekarang ini. Baik mengenai perusahaannya, maupun mengenai produk-produk apa saja yang dihasilkan oleh PTDI sendiri. Masyarakat umum hanya mengetahui PTDI secara general saja yaitu, sebuah industri pesawat terbang di Indonesia yang merupakan Badan Usaha Milik Negara.

Kenyataannya PTDI masih aktif beroperasi dalam bidang aircraft service, engineering service, dan pembuatan komponen-komponen pesawat walaupun belum kembali aktif dalam pembuatan pesawat. Namun dengan kurangnya pengetahuan masyarakat mengenai keberadaan dan perkembangan PTDI yang sekarang, keadaan tersebut menyulitkan PTDI dalam memperkenalkan produk-produknya terutama sekarang ini dengan dihasilkannya produk baru berupa pesawat terbang oleh PTDI yaitu N219, jenis pesawat berkapasitas kecil yang mampu menampung sembilan belas penumpang.

Masyarakat sebagai pihak ketiga bagi PTDI, memiliki peran besar sebagai perusahaan BUMN. Sebagai perusahaan Kedirgantaraan, opini dari masyarakat menentukan pandangan customer terhadap perusahaan. Setiap pendapat yang dikemukakan oleh masyarakat akan menjadi bahan pertimbangan bagi customer dalam menilai PTDI.

Pandangan ataupun opini dari masyarakat dapat memberikan pengaruh bagi stakeholder PTDI dalam mengambil keputusan. Stakeholder, sebagaimana dikatakan oleh (Matuleviciene \& Stravinskiene, 2015), merupakan sumber daya 
organisasi yang memiliki peran penting bagi organisasi, tidak hanya untuk mengendalikan kestabilan organisasi, namun juga untuk membentuk reputasi organisasi.

Salah satu upaya yang dilakukan oleh manajemen PTDI dalam upaya memulihkan reputasi perusahaan adalah melalui kegiatan open house. PTDI berusaha menggandeng masyarakat luas untuk lebih mengenali PTDI, baik mengenai perusahaan atau produkproduknya dengan pendekatan yang informal melalui penyediaan beragam fasilitas hiburan. Bertujuan untuk mengedukasi masyarakat, terutama warga Kota Bandung mengenai PTDI dan dengan harapan dapat membangun kembali brand awareness masyarakat terhadap PTDI.

Open house sendiri sudah ada semenjak kepemimpinan Pak Habibie di PTDI yaitu sekitar tahun 80-an. Namun sejarah pembentukan open house sendiri pada awalnya bertujuan untuk kepentingan internal PTDI, yaitu sebagai employee relations. Dimana karyawan diberikan kesempatan selama satu hari untuk turut serta membawa keluarganya ke lingkungan kerja, memperlihatkan dan memperkenalkan seperti apa lingkungan kerja karyawan di PTDI kepada keluarga. Namun pada awal tahun 2000-an pembuatan open house berubah fokus menjadi kepada masyarakat luar bukan kepada keluarga karyawan lagi, tujuannya pun berubah.

Rancangan kegiatan open house sendiri, dilaksanakan berdasarkan proses public relations, dimana pada tahapannya panitia melakukan riset, yang dilanjutkan pada tahap perencanaan, lalu pelaksanaan kegiatan, dan terakhir adalah melakukan evaluasi. Keempat hal tersebut menjadi poin penting yang dilakukan oleh pihak panitia dalam menentukan dan merancang kegiatan open house seperti apa yang tepat untuk mencapai tujuan yang diinginkan perusahaan.

Perencanaan open house sendiri telah dilakukan tiga sampai empat bulan menjelang bulan Agustus oleh Divisi Humas PTDI. Dengan terbentuknya kepanitiaan tersebut, penetapan tanggal dan konten acara mulai dibuat. Yang menjadi pertimbangan utama dalam pembuatan open house adalah perihal keamanan perusahaan.

Fasilitas pada perusahaan seperti mesin, pesawat, dan komponennya merupakan barang mahal, kerusakan pada fasilitas tersebut akan membawa kerugian yang besar kepada perusahaan. Untuk itu adanya koordinasi yang baik dari pihak fasilitas kepada karyawan pabrik bersama keamanan, menjadi fokus utama yang menjadi pertimbangan pada pembuatan acara. Adapun hal lain yang dilakukan adalah, memberikan garis pembatas pada fasilitas yang dapat dikunjungi selama tour.

Faktanya perubahan yang disebut telah dilakukan oleh pihak PTDI dalam kegiatan 
open house nya tersebut belum menunjukan perubahan positif yang sigifikan mengenai kesadaran masyarakat akan PTDI. Hal ini berkaitan dengan yang dilakukan oleh panitia dalam Proses PR pada kegiatan open house tersebut.

Tentunya pada setiap proses public relations dalam sebuah kegiatan memiliki cara masingmasing yang disesuaikan dengan kebutuhan perusahaannya. Hal-hal tersebut yang mungkin dapat memengaruhi berjalannya kegiatan baik secara positif maupun negatif.

Seperti halnya yang dilakukan oleh PTDI dimana dalam penanggungjawaban pihak panitia memilih untuk memisahkan antara konseptor acara sebagai otak dari perancangan kegiatan, dan penanggung jawab lapangan yang menangani permasalahan teknis utamanya dalam aktivitas Plant Tour, daya tarik utama pada kegiatan open house PTDI. Nyatanya pemisahan pada kepanitiaan tersebut kurang lebih memunculkan beberapa permasalahan yang pada akhirnya memengaruhi jalannya proses dalam kegiatan open house tersebut.

Berdasarkan konteks penelitian tersebut penulis tertarik untuk meneliti proses public relations pada kegiatan open house PTDI dalam membangun brand awareness, yang menurut (Aaker, 1995), Brand awareness adalah kemampuan dari seseorang yang merupakan calon pembeli (potential buyer) untuk mengenali (recognize) atau menyebutkan kembali (recall) suatu merek merupakan bagian dari suatu kategori produk.

Pada umumnya konsumen cenderung membeli produk dengan merek yang sudah dikenalnya atas dasar pertimbangan tertentu seperti kenyamanan, keamanan, menghindarkan risiko karena sudah pernah mengkonsumsi. Kesadaran merek merupakan key of brand asset atau kunci pembuka untuk masuk ke elemen lainnya. Jadi, jika kesadaran itu sangat rendah maka hampir dipastikan bahwa ekuitas mereknya juga rendah (Septiani, Sumartias, \& Perbawasari, 2017).

Terdapat tiga tipe brand awareness, yaitu: brand recognition, category-cued brand-name recall dan brand recall-boosted recognition. (Rossiter, 2014).

\section{Meningkatkan brand awareness PTDI di} masyarakat melalui kegiatan open house ini jika dilihat melalui pelaksanannya merupakan suatu model PR yang dikembangkan oleh (Cutlip, Center, \& Broom, 2008), yaitu empat tahap proses PR, yang terdiri dari; Pertama, mendefinisikan masalah (analisis situasi). Kedua, perencanaan dan pemograman. Ketiga, mengambil tindakan dan berkomunikasi dan Keempat, evaluasi program.

\section{METODE PENELITIAN}


menjelaskan jenis penelitian, subjek dan objek penelitian, waktu dan lokasi penelitian, instrumen penelitian, cara pengambilan sampel, pengumpulan data, dan analisis data. Subjek dalam penelitian ini adalah staf Divisi Humas dan Divisi Protokol PTDI, yang menjalankan kegiatan open house dalam membangun kembali brand awareness terhadap PTDI.

Objek dalam penelitian ini adalah PTDI. PTDI merupakan salah satu perusahaan BUMN yang berada dibawah naungan pemerintah, bergerak di bidang kedirgantaraan dan aktif dalam membuat pesawat terbang (helikopter dan pesawat kecil dengan kapasitas penumpang yang sedikit), komponen-komponen pesawat, sistem senjata (roket dan torpedo), engineering service, dan aircraft service.

PTDI merupakan satu-satunya perusahaan kedirgantaraan di Asia Tenggara yang berpengalaman dan berkompetensi dalam rancang bangun, pengembangan, dan manufacturing pesawat terbang. PTDI telah memproduksi berbagai macam pesawat terbang, baik sipil, militer, maupun spesial misi seperti halnya Maritime Patrol Aircraft.

PTDI sendiri kini telah membuktikan dirinya sebagai perusahaan kedirgantaraan di Indonesia dan mampu menghasilkan produk yang kualitasnya dapat dipercaya, dengan adanya kerja sama yang dilakukan oleh pihak Airbus Military, dalam memproduksi komponen pada pesawatnya untuk dibuat oleh pihak PTDI. Selain itu, pembuatan pesawat kecil berkapasitas 19 penumpang, yang dibangga-banggakan sebagai 'Hasil Karya Anak Bangsa' karena $60 \%$ dari pesawat N219 tersebut ditangani oleh engineer, teknisi dan karyawan asli orang Indonesia. Komponen-komponen pada pesawat juga dibuat dan dirakit di Indonesia.

Penelitian ini menggunakan paradigma positivisme. Peneliti menggunakan paradigma positivisme karena di dalam penelitian ini peneliti ingin mengungkapkan kebenaran dan realitas proses public relations yang dilakukan oleh PTDI secara objektif dan berdasarkan pada konsep proses public relations oleh Cutlip, Center and Broom.

Paradigma positivisme berupaya mengungkapkan kebenaran realitas yang ada dan bagaimana realitas tersebut senyatanya berjalan (Salim, 2006). Paradigma positivistik (fakta sosial) menganggap realitas itu sebagai sesuatu yang empiris atau benar-benar nyata dan dapat diobservasi. Dalam meneliti, peneliti dan objek yang diteliti bersifat independen dan saling tidak berinteraksi.

Menurut paradigma ini, setiap tindakan dapat diterangkan sebagai hasil atau akibat dari suatu sebab sesungguhnya yang mendahului akibat tersebut secara sementara. Sehingga peneliti harus bertanya secara langsung kepada objek yang diteliti, dan sang objek dapat 
memberikan jawaban langsung kepada peneliti.

Guna mengobservasi hakikat realitas seperti apa adanya dan untuk menjaga objektivitas temuan, hubungan epistemologi tersebut harus menempatkan penelitian di belakang layar. Ini bertujuan agar hasil yang didapatkan bisa seobjektif mungkin dan menggambarkan keadaan yang sebenarnya serta agar peneliti dapat menemukan derajat presisi yang tinggi dalam penelitian.

Penelitian ini menggunakan metode deskriptif dengan data kualitatif. Metode deskriptif adalah suatu metode yang meneliti status sekelompok manusia, suatu objek, suatu set kondisi, suatu sistem pemikiran, ataupun suatu kelas peristiwa pada masa sekarang. Tujuan dari penelitian deskriptif ini adalah membuat deskripsi, gambaran secara sistematis, faktual dan akurat mengenai fakta-fakta, sifatsifat atau hubungan antar fenomena yang diselidiki.

Peneliti menggunakan metode deskriptif karena dalam penelitian ini peneliti melakukan observasi dan memaparkan suasana ilmiah yang terjadi dan peneliti bertindak sebagai pengamat dan peneliti mencari data bukan untuk menguji data. Pada penelitian ini, penulis melakukan penentuan sumber data dengan menggunakan teknik purposive sampling. Teknik purposive sampling menurut (Sugiyono, 2012) adalah teknik pengambilan sumber data dengan pengembangan tertentu pertimbangannya adalah kriteria yang telah ditentukan oleh peneliti.

Pemilihan metode purposive sampling diharapkan kriteria sampel yang diperoleh benar-benar sesuai dengan penelitian yang akan dilakukan. Pertimbangan tertentu ini misalnya orang tersebut yang dianggap paling tahu tentang apa yang kita harapkan atau mungkin dia sebagai penguasa sehingga akan memudahkan peneliti menjelajahi objek/situasi sosial yang diteliti.

Teknik pengumpulan data di lapangan yang dilakukan dalam penelitian ini berupa wawancara yang dilakukan dengan intensif agar mendapatkan data yang akurat. Selanjutnya pengumpulan data yang dilakukan adalah observasi dengan melakukan observasi non partisipan dan terakhir dilakukan dengan studi pustaka.

Analisis data dalam penelitian kualitatif, dilakukan pada saat pengumpulan data berlangsung, dan setelah selesai pengumpulan data dalam periode tertentu. Pada saat wawancara langsung dengan informan dari PTDI, peneliti sudah melakukan analisis terhadap jawaban yang diwawancarai. Bila jawaban yang diwawancarai setelah dianalisis terasa belum memuaskan, maka peneliti akan melanjutkan pertanyaan lagi, sampai peneliti puas dengan jawaban yang dikemukakan oleh 
key informant, diperoleh data yang dianggap kredibel.

Analisis data yang digunakan dalam penelitian ini adalah analisis data dari Miles dan Huberman yakni analisis data dilakukan hingga datanya sudah jenuh. Aktivitas dalam analisis data adalah data reduction (reduksi data), data display (penyajian data), dan conclusion drawing/verification (penarikan kesimpulan dan verifikasi) (Sugiyono, 2012).

Teknik validitas dan keabsahan data dalam penelitian ini menggunakan triangulasi sumber data. Triangulsi dalam pengujian kredibilitas ini diartikan sebagai pengecekan data dari berbagai sumber dengan berbagai cara dan berbagai waktu (Sugiyono, 2012). Menggunakan teknik triangulasi sumber data untuk membandingkan derajat kepercayaan suatu data yang diperoleh dengan cara dan waktu pengumpulan data yang berbeda.

\section{HASIL DAN PEMBAHASAN}

Hasil penelitian ini mengacu pada tujuan peneliti, yaitu untuk proses public relations yang terjadi di dalam kegiatan diantaranya adalah mengetahui riset, perencanaan, pelaksanaan, dan evaluasi yang dilakukan oleh PTDI dalam melaksanakan kegiatan open house tersebut.

Penelitian ini menggunakan teknik purposive sampling dengan narasumber yang telah ditetapkan sebelumnya dan dianggap menguasai kegiatan open house karena berperan aktif dalam kegiatan dan memiliki pengalaman dalam kegiatan open house tersebut. Lalu menentukan narasumber yang secara keseluruhan telah memenuhi kriteria informan yang telah dibuat dan ditetapkan oleh peneliti berdasarkan ketetapan dari sampling purposive tersebut. Adapun peneliti telah menggali informasi mengenai objek penelitian sesuai dengan judul maupun rumusan masalah yang telah ditetapkan.

Peneliti mendapatkan data mengenai riset yang dilakukan pihak PTDI dalam melaksanakan kegiatan open house, perencanaan kegiatan open house, tahap pelaksanaan kegiatan open house, serta evaluasi yang dilakukan oleh PTDI dalam melaksanakan kegiatan open house dalam rangka membangun kembali brand awareness masyarakat

Peneliti melakukan wawancara dengan informan, yaitu pihak-pihak yang terlibat dalam kepengurusan HUT PTDI utamanya panitia pada kegiatan open house yang berada dibawah tanggung jawab Sekretaris Perusahaan (Sekper) Pihak-pihak ini terdiri dari Divisi Humas dan Divisi Protokol PTDI, yang dibantu oleh divisi lainnya seperti marketing.

Peneliti akan membahas dan menganalisis seluruh data-data yang telah dikumpulkan dan diperoleh melalui data wawancara, observasi, serta studi pustaka dengan pihak yang sudah 
ditetapkan kriterianya oleh peneliti. Hasil penelitian ini mengacu pada tujuan penelitian yang hendak dicapai yaitu untuk mengetahui Proses PR dalam kegiatan open house yang diselenggarakan untuk membangun kembali Awareness masyarakat mengenai PTDI.

Riset diawal sangat diperlukan agar dapat memperoleh data dan fakta yang aktual sebagai bahan perencanaan atas kegiatan yang akan dilakukan dan bagaimana cara melakukannya secara tepat. Hasil wawancara dengan Kepala Divisi Humas PTDI Irland Budiman, yang menjelaskan bahwa:

"Riset sebenarnya tidak dilakukan secara mendalam akan tetapi humas melihat dari suatu animo masyarakat, yang kami lakukan adalah menelaah kembali filosofi dari open house itu sendiri, salah satunya tujuan dari open house yang diadakan untuk masyarakat. Karena tidak semua masyarakat Indonesia khususnya Bandung bisa melihat industri pesawat terbang secara langsung. Jadi dasarnya dari perusahaan sendiri yang merupakan industri pesawat terbang yang tertutup dan terbatas. Melalui perayaan ulang tahun PTDI tepatnya pada kegiatan open house diperlihatkan seperti apa industri pesawat terbang itu."(Budiman, 2016)

Awal mulanya open house ini dilaksanakan sebagai kegiatan rutin PTDI yang dilaksanakan setiap tahun bertepatan dengan rangkaian HUT PTDI, tujuannyatidaklainsebagai saranahiburan bagi karyawan dan keluarga karyawan semata.
Namun pada pelaksanaan HUT PTDI yang ke40 open house dipisahkan dari segi kepanitiaan, dan open house dijadikan sebagai main event dari rangkaian kegiatan HUT PTDI. Alasan pemisahan itu pun salah satunya berkenaan dengan semakin menurunnya awareness masyarakat mengenai keaktifan PTDI dalam memproduksi pesawat terbang. PTDI dianggap menggantungkan hidup perusahaan melalui jalan lain selain memproduksi pesawat terbang. Kesadaran masyarakat mengenai PTDI tersebut dapat dikategorikan tingkatannya berdasarkan piramida brand awareness oleh Aaker. Hal ini pun diperkuat dengan penjelasan oleh Irland Budiman selaku Ketua Divisi Humas PTDI bahwa masih banyak masyarakat Bandung berada pada tingkatan brand recognition, yaitu pengenalan terhadap merek terhadap PTDI yang merupakan tingkatan minimal dari piramida kesadaran merek. Namun jika dibandingkan dengan kondisi pada awal perusahaan sendiri berdiri, hasilnya sangat menurun.

Penurunan pada awareness masyarakat ini terjadi setelah PTDI dipailitkan pada tahun 2007 silam oleh Pengadilan Negeri Jakarta. Setelah kejadian tersebut PTDI telah melakukan berbagai usaha untuk mengembalikan nama baik PTDI melalui pemberitaan di media, ikut aktif dalam dunia media sosial, dan mengikuti beberapa kegiatan pameran yang diadakan di seluruh Indonesia maupun luar negeri. 
Namun peningkatan yang dilakukan belum tampak jelas. Seperti dijelaskan oleh Adisatryo, salah satu Staff Divisi Humas PT Dirgantara Indonesia, bahwa:

"Karena sempat dipailitkan itu makanya jadi citra kita begitu buruk. Padahal kita sudah aktif, media juga gencar ngeberitain cuman kan masyarakat itu masih banyak yang tidak tahu karena tidak berusaha juga mencari tahu tentang PTDI. Karena masyarakat pada dasarnya butuh hasil yang keliatannya itu. Si produknya memang mereka liat seperti apa" (Adisatryo, 2016).

Kesulitan dalam meningkatkan awareness masyarakat ini juga disebabkan oleh jenis perusahaan sendiri sebagai salah satu industri strategis yang merupakan bagian dari pertahanan negara, memiliki aturan ketat dalam menampilkan barang produksinya kepada masyarakat karena banyak diantara produk tersebut merupakan produk milik militer. Hal ini di jelaskan oleh Kerry Apriawan salah satu staff Divisi Humas PTDI:

"Sebagai salah satu BUMN industri strategis, dengan peraturan yang ketat tentu mempersempit ruang gerak perusahaan dalam mendekatkan diri kepada masyarakat utamanya Divisi Humas dalam membangun kembali kesadaran masyarakat akan PTDI. Adapun pendekatan yang dilakukan oleh PTDI harus dilaksanakan dengan cara yang berbeda. Jika melihat dari jenis produk yang dihasilkan oleh perusahaan sendiri, sebenarnya PTDI memiliki produk yang menarik karena di Asia Tenggara menjadi satu-satunya perusahan yang memproduksi pesawat terbang. Keunikan pada produknya tersebutlah yang harus dimanfaatkan secara kreatif oleh Divisi Humas. Pendekatan dan tampilan pada pesan yang ingin disampaikan dapat dikemas secara unik." (Apriawan, 2016).

Namun dengan adanya inovasi baru dari PTDI ini, yaitu sebuah pesawat terbang untuk sarana transportasi umum dengan muatan sedikit, tujuannya adalah untuk mempermudah akses antar pulau di Indonesia. Maka PTDI harus mempertimbangkan konsumen sebagai yang nantinya akan membeli. Menilai dari target sasarannya yaitu masyarakat umum, PTDI harus lebih mendekatkan diri kepada masyarakat, untuk memperkenalkan perusahaan utamanya meyakinkan masyarakat terhadap produk tersebut, sebagaimana dikutip dari wawancara Kerry Apriawan berikut:

"minat dalam mempersiapkan sumber daya manusianya agar masyarakat berminat menguasai ilmu pengetahuan dan teknologi yang berdedikasi tinggi menggunakan kepandaian dan keterampilannya bagi pembangunan industri pesawat terbang perancang pesawat, baik sebagai orang yang mengetahui cara memasarkan produk pesawat terbang secara nasional maupun internasional dan tentunya agar seluruh masyarakat Indonesia mempunyai kebanggaan terhadap produk buatan dalam negeri. siapa lagi yang bisa memajukan PT DI, kalau bukan masyarakat sendiri, kita ingin membentuk opini di mata masyarakat 
bahwa produk buatan anak-anak bangsa kualitasnya tidak kalah dengan negaranegara yang sudah lebih maju dari kita.’(Apriawan, 2016)

Lebih lanjut Kerry Apriawan menjelaskan seberapa pentingnya membangun kembali awareness masyarakat terhadap PTDI, bersamaan dengan dirpoduksinya pesawat terbang baru yang ditujukan untuk masyarakat umum tersebut:

"Untuk keberlangsungan PTDI sendiri sebagai perusahaan dalam bidang kedirgantaraan. Apalagi dengan kemunculan produk baru yang sekarang lagi digarap itukan fokusnya untuk komersil, masyarakat juga yang akan menikmati fasilitas tersebut. Maskapai pesawat yang mana merupakan konsumen kita, mana mau beli kalau konsumen mereka meragukan produk buatan PTDI. Jadi efek domino buat kitanya juga. Makanya melalui kegiatan open house ni kami mencoba untuk membangun kembali awareness masyarakat terhadap PTDI dengan mengedukasi masyarakat mengenai perusahaan, yang utamanya mengenai produk yang kami lagi buat ini”" (Apriawan, 2016).

Melihat kembali dari sisi perusahaan sebagai BUMN, awareness masyarakat juga berperan penting guna mendapatkan dukungan dari pemerintah atas kegiatan atau aktivitas perusahaan yang akan dilakukan kedepannya. Nadine, selaku staff Divisi Protokoler PTDI menyatakan:

"Sangat penting berarti masyarakat mendukung kegiatan yang dilaksanakan PTDI mendukung kegiatan perusahaan, citra PTDI juga jadi baik lagi. Apalagi untuk pemerintah, yang paling penting didukung pemerintah apalagi kita perusahaan BUMN dukungan pemerintah itu sangat berharga."(Nadine, 2017)

Sulhan Safi'i, sebagai triangulator penelitian berpendapat mengenai arti brand awareness bagi sebuah perusahaan, adalah:

"Brand awareness sangatlah penting, karena merupakan image dari sebuah perusahaan. Orang tidak akan melihat berapa jumlah karyawan yang dimiliki oleh sebuah perusahaan, yang mereka lihat adalah seberapa hebatnya brand mereka di kenal di masyarakat. sebagai contoh coca cola. Semua perusahaan wajib memiliki planning yang bagus untuk menentukan positioning perusahaan yang diinginkan semenjak perusahaan lahir. Ketika suatu brand telah dikenal masyarakat, sebanyak apapun pesaing yang muncul posisi brand tersebut tetap kuat, dan hal akan berlangsung lama" (Safi'i, 2017).

Berdasarkan penuturan Sulhan Safi'i tersebut dapat ditarik kesimpulan seberapa berpengaruhnya brand awareness perusahaan demi keberlangsungan perusahaanya itu sendiri. Kaitannya adalah dengan pemasukan yang akan diterima berdasarkan ketertarikan konsumen untuk lebih memilih brand kita.

Riset di awal sangat perlu dilakukan agar 
dapat memperoleh data dan fakta yang aktual sebagai bahan perencanaan sebuah kegiatan yang tepat. Sebagai penyelenggara kegiatan open house panitia yang terdiri dari karyawan PTDI khususnya Divisi Humas dan Divisi Protokoler, terlebih dahulu melakukan sebuah riset kecil untuk mengetahui bagaimana tanggapan dan gambaran masyarakat Bandung kini terhadap perusahaan.

Menurut hasil penelitian yang telah dipaparkan sebelumnya, panitia kegiatan open house melakukan riset di lapangan untuk mengetahui tanggapan masyarakat mengenai PTDI. Menurut Jefkins (2004: 296), riset lapangan (field research) adalah riset yang diselenggarakan dengan cara mengadakan serangkaian wawancara dengan sejumlah responden di lapangan. Ini berarti, para pewawancara harus turun langsung untuk menemui para respondennya tersebut.

Proses riset dan analisis yang digunakan oleh PTDI dalam melihat kondisi yang ada di masyarakat sekarang ini yaitu menggunakan metode informal, dengan melakukan tinjauan dan pengumpulan data sekunder mengenai pemberitaan PTDI di media massa, dimana data yang dikumpulkan merupakan hasil dari pengumpulan data orang lain seringkali dengan tujuan yang berbeda.

Hasil wawancara terhadap informan mengenai riset yang dilakukan dalam melakukan kegiatan open house adalah: (1) Pelaksanaan riset hanya dilakukan oleh Divisi Humas sebagai konseptor yang bertanggung jawab dalam merancang kegiatan yang tepat., (2) Bentuk riset yang dilakukan berupa riset informal yaitu penelusuran data sekunder berupa monitoring dengan cara melihat pemberitaan mengenai PTDI yang ada di media cetak, elektronik, maupun media online. Pengumpulan opini yang didapatkan dari tamu yang melakukan kunjungan ke perusahaan., (3) Gambaran Proses Riset yang dilakukan oleh Divisi Humas dalam kegiatan open house PTDI., (4) Melalui hasil riset, penyelenggara dapat menentukan kegiatan yang tepat yang sesuai dengan kondisi saat ini.

Riset yang dilakukan oleh Divisi Humas PTDI dirasa kurang untuk dapat memenuhi kriteria atau harapan akan keberlangsungan kegiatan open house. Riset melalui penelusuran data sekunder tidak cukup untuk memenuhi kebutuhan panitia dalam mengetahui cara yang paling tepat untuk menyampaikan pesan perusahaan kepada masyarakat melalui kegiatan open house tersebut.

Menurut (Jefkins, 2004) dalam buku Public Relations disebutkan bahwa cara untuk mengenali situasi sebenarnya lebih dari sekedar pengumpulan pendapat. Banyak cara yang bisa dilakukan untuk itu, antara lain salah satunya dengan survei-survei yang khusus diadakan 
untuk mengungkapkan pendapat, sikap-sikap masyarakat, atau citra organisasi dimata khalayaknya dan pemantauan berita-berita di media massa

Perencanaan dengan menetapkan tujuan dan hasil yang diinginkan dalam menyusun kegiatan open house oleh panitia pelaksana merupakan langkah penting yang harus dilakukan, sebagaimana disinyalir oleh (Odom \& Strout-Dapaz, 2008), bahwa langkah pertama dan terpenting dalam perencanaan kegiatan open house adalah menetapkan tujuan umum, tujuan khusus dan hasil yang diinginkan (the goals, objectives and desired outcomes).

Penyusunan perencanaan suatu kegiatan dibutuhkan pemahaman terhadap situasi yang ada. Hal ini sangat diperlukan guna mengukur kemampuan dan kapabilitas dari SDM yang melaksanakan kegiatan, sebelum merumuskan suatu program hendaknya kita mengetahui keadaan dan situasi yang sedang dihadapi perusahaan sebagai awal dari kekuatan dan kesempatan dalam melakukan strategi yang tepat. Tanpa materi dan pengkomukasian yang tepat, maka akan menjadi kendala bagi perusahaan sendiri, yang menyebabkan pesan tidak tersampaikan kepada masyarakat.

Perencanaan dan pemograman merupakan segala informasi atau data masukan atau input yang diperoleh berkaitan dengan hal atau permasalahan yang dihadapi ke dalam bentuk rencana tindakan untuk pemecahannya. Perencanaan public relations merupakan suatu proses berkesinambungan dan selalu memerlukan peninjauan agar tindakan yang diambil sesuai dengan aturan yang ditetapkan. Sejumlah prinsip yang harus diperhatikan dalam perencanaan program antara lain: sifat, waktu, dan lingkungan. Perencanaan juga harus memperhatikan situasi di dalam maupun di luar organisasi, serta pihak-pihak yang terlibat dalam perencanaan tersebut (Cutlip et al., 2008).

Menetapkan susunan kepanitiaan dengan cara membagi tanggungjawab dimana Divisi Protokol sebagai pelaksana lapangan dan Divisi Humas sebagai konseptor melanjutkan dari proses riset yang mereka kerjakan.

Khalayak sasaran dari kegiatan open house ini adalah masyarakat Indonesia, khususnya masyarakat Bandung yang berada disekitar wilayah perusahaan. Fokus utama khalayak ada pada masyarakat yang tidak dapat mengunjungi perusahaan di waktu kunjungan pada hari biasa, seperti anak-anak dan orang tua.

Tujuan open house itu untuk membangun kembali brand awareness terhadap perusahaan, agar masyarakat menjadi tahu mengenai aktivitas yang dilakukan oleh perusahaan kini, setelah tahu diharapkan masyarakat paham, yang membawa sikap masyarakat untuk mencari tahu mengenai perusahaan, dan akhirnya sikap masyarakattersebutmembantukeberlangsungan 
perusahaan dalam membangun opini positif. Menyusun isi pesan yang disampaikan, seperti siapa yang mengkomunikasikannya, seperti apa pesannya agar tujuan yang dimaksud dapat tercapai juga merupakan bagian dari proses perencanaan.

Panitia open house yang terdiri dari Divisi Humas dan Divisi Protokol bekerjasama dalam kegiatan untuk menyampaikan informasi dan memberikan pengertian kepada masyarakat mengenai perusahan untuk mengedukasi agar masyarakat lebih tahu, mengerti, dan paham bagaimana aktivitas perusahaan, bagaimana aktivitas sebuah perusahaan Kedirgantaraan, bagaimana produktivitas perusahaan.

Cutlip (2008) menyatakan bahwa pesan harus sesuai dengan kapasitas pemahaman penerima dan relevan dengan kepentingan atau kebutuhan penerima, terakhir pesan harus memotivasi kepentingan penerima dan menimbulkan respons. Dengan kata lain isi pesan yang disampaikan memiliki peran penting karena berpengaruh terhadap kesuksesan dari tujuan yang ingin dicapai itu sendiri. Oleh karena itu isi pesan yang memberikan pemahaman mengenai perusahaan Kedirgantaraan dan produktivitas perusahaan dibutuhkan jika inginmeningkatkan brand awareness PTDI di masyarakat.

Sekper merupakan penanggung jawab tertinggi dari kegiatan membawahi Divisi
Humas dan Divisi Protokol. Adapun pengkomunikasian mengenai keberlangsungan acara selain melalui poster dan baligho, Divisi Humas memanfaatkan media sosial karyawan. Anggaran pada kegiatan sebagai perusahaan BUMN tidak mengalami perubahan yang signifikan.

Isi pesan yang disampaikan adalah mengenai masih aktifnya PTDI dalam memproduksi pesawat terbang dan adanya produk baru N219. Pesan disampaikan secara tersurat melaui kegiatan Plant Tour, dengan komunikator yang dipilih oleh Divisi Protokol adalah karyawan muda dari divisi Marketing dengan alasan memperlihatkan masih hidupnya perusahaan jika memperlihatkan karyawan muda. Adapun pesan tersirat yang disampaikan melalui flight simulator.

Pemisahan tanggung jawab antara Divisi Humas dan Divisi Protokol, memisahkan perencanaan dan pelaksanaan yang dilakukan oleh kedua divisi walaupun bekerja pada kegiatan yang sama. Adapun kelemahan pada pemisahan tanggung jawab ini terlihat jelas yaitu pada jumlah orang yang membantu berjalannya kegiatan. Kelemahannya terdapat pada minimnya SDM pada kegiatan, mengingat jumlah karyawan pada masing-masing divisi juga tidak memenuhi, maka harus ditarik anggota kepanitiaan dari divisi lain yang sesungguhnya tidak terlalu memahami permasalahan yang 
ingin diselesaikan oleh Divisi Humas dan kurang memahami ide mengenai brand awareness ini.

Menurut Rusady Roeslan, dalam analisis hasil akhir, seorang public relations officer mengidentifikasi hasil akhir atau evaluasi yang lebih bersifat checkpoint satu persatu dari komponen atau tahapan-tahapan perencanaan dan kegiatan, apakah sudah berjalan atau belum. Hasil evaluasi dapat memberikan gambaran secara kuantitatif dan kualitatif, bahwa program sudah dapat memenuhi persyaratan atau masih terjadi kekurangan. Aktivitas diteliti dan dianalisis secara seksama dari berbagai persoalan atau pihak yang terlibat, kemudian ditarik suatu kesimpulan tentang sukses atau tidaknya $P R$ programming \& communication tersebut (Soemirat \& Ardianto, 2010).

Proses Evaluasi yang dilakukan oleh panitia kegiatan open house adalah manajer dari masing-masing divisi melakukan evaluasi bersama Sekper, hasil evaluasi para manajer dengan Sekper disampaikan kembali melalui rapat yang dilakukan masing-masing divisi secara terpisah, yaitu Divisi Humas dan Divisi Protkol. Hal-hal yang dibahas pada rapat evaluasi tersebut lebih kepada teknis di lapangan pelaksanaan kegiatan open house.

Cara panitia untuk mengetahui feedback pengunjung kegiatan open house adalah melalui pengumpulan opini yang diberikan masyarakat kepada panitia ketika kegiatan tengah berlangsung. Kedua, melalui pemberitaan di media, dan ketiga permintaan kunjungan harian ke perusahaan setelah kegiatan dilaksanakan. Evaluasi yang dilakukan oleh panitia tersebut, dalam pandangan (Watson, 2012) masih menunjukkan cara-cara pengukuran dan evaluasi aktivitas public relations yang biasa dilakukan pada pertengahan abad 20 seperti; pengukuran opini dan publisitas di media. Kunci utama mengevaluasi apa yang dipelajari orang dari suatu program (atau sumber yang bersamaan) adalah dengan mengukur variabel pengetahuan, kesadaran dan pemahaman sebelum program dimulai. Hal itu dilakukan untuk menentukan perubahan. Harus dibuat perbandingan antara setidaknya dua ukuran yang dapat dibandingkan, jumlah orang yang mengubah sikapnya, dab jumlah orang yang bertindak sesuai dengan keinginan (Cutlip, 2008).

Menurut Coulson, tanpa evaluasi, kita tidak dapat menentukan sejauh mana sasaran yang telah dicapai. Evaluasi dapat pula mengusulkan penambahan sarana untuk meningkatkan prestasi, agar dapat mendekati prestasi yang diharapkan sehingga pada gilirannya, dapat membawa ke arah modifikasi program (Soemirat \& Ardianto, 2010).

\section{SIMPULAN}

Berdasarkan hasil penelitian yang 
diperoleh melalui wawancara dan observasi oleh peneliti, peneliti telah melakukan analisis dan pembahasan yang sudah diuraikan pada bab sebelumnya, maka simpulan yang dapat ditarik dari penelitian "Proses public relations Pada kegiatan open house PTDI dalam membangun brand awareness" adalah sebagai berikut:

Pertama, tahap riset dalam kegiatan open house PTDI dalam membangun kembali brand awareness di masyarakat Bandung ini dilakukan dengan cara mengumpulkan data oleh Divisi Humas melalui jumlah permintaan kunjungan harian ke PTDI. Hal yang berkaitan dengan latar pendidikan, jenis instansi, range usia, dan asal daerah yang tertarik melakukan kunjungan perusahaan menunjukkan seberapa jauh masyarakat Bandung yang tahu mengenai keberadaan perusahaan, dan sejauh apa keberhasilan PTDI dalam mengenalkan perusahaannya kepada masyarakat. Berikutnya Divisi Humas juga mengumpulkan pendapat kepada para permintaan kunjungan harian ke perusahaan apa saja yang masyarakat ketahui mengenai PTDI sekarang ini. Namun tidak adanya standar yang jelas dalam pelaksanaan riset, seperti pertanyaan seperti apa yang ditanyakan membuat riset yang dilakukan oleh PTDI selalu berubah, tidak tentu dan terkadang tidak memberikan jawaban akurat atas apa yang ingin dicari tahu. Pelaksanaannya hanya berbekal tujuan dalam mencari tahu bagaimana pandangan masyarakat mengenai perusahaan kini, dan sejauh apa kesadaran masyarakat Bandung mengenai PTDI.

Kedua, tahap perencanaan dalam kegiatan open house PTDI dalam membangun kembali brand awareness di masyarakat diawali dengan melakukan pemisahan tanggung jawab dimana divisi humas sebagai konseptor dan divisi protokol sebagai pelaksana lapangan. Namun pemisahan ini, ternyata memisahkan proses perencanaan yang dilakukan keduanya, sehingga tidak semua ide dan pemikiran divisi humas mengenai konsep baru yang ingin dilakukan melalui kegiatan open house sampai dan dipahami oleh divisi protokol. Alhasil perencanaan yang dilakukan divisi protokol pun cenderung tidak berubah dari kegiatan open house sebelumnya. Hal ini mengakibatkan kerja yang kurang sinkron di antara kedua divisi untuk mencapai tujuan.

Ketiga, tahap pelaksanaan pada kegiatan open house PTDI diawali dengan mengkomunikasikan pelaksanaan acara kepada masyarakat. Adapun yang dilakukan oleh Divisi Protokol adalah dengan mengundang tokoh penting masyarakat sekitar dan sekolah-sekolah yang masih berada di wilayah lingkungan perusahaan, sedangkan Divisi Humas melakukan dengan penyebaran brosur, baligho. Untuk media lain yang digunakan selain media sosial perusahaan, Divisi Humas memanfaatkan 
media sosial pribadi karyawan PTDI. Untuk tourguide yang mewakili sebagai pembicara perusahaan ditentukan oleh Divisi Protokol adalah karyawan muda dari Divisi Marketing, dengan alasan fleksibilitas kaum muda yang lebih mudah didekati oleh pengunjung dan juga memperlihatkan kepada masyarakat bahwa PTDI masih hidup dengan adanya generasi baru di dalam perusahaan. Adapun kekurangan yang dirasakan adalah belum cukupnya ilmu mengenai dunia kedirgantaraan dan mengenai perusahaan.

Keempat, tahap evaluasi dalam kegiatan open house PTDI dalam membangun kembali Brand awareness di masyarakat Bandung masih sangat kurang. Proses evaluasi yang dilakukan setelah kegiatan open house dilakukan secara terpisah antara Divisi Humas dan Divisi Protokol sebagai panitia penanggung jawab utama dalam kegiatan, hanya rapat internal tiap divisi saja dilakukan, akibatnya pandangan divisi lain terhadap tugas yang dilakukan oleh divisinya tidak tersampaikan secara langsung, padahal pandangan ini dapat menjadi masukan yang bisa diimplementasikan untuk membuat kegiatan selanjutnya lebih baik lagi. Merubah cara kerja agar menjadi lebih efektif dalam mencapai tujuan. Tidak ada pengukuran yang jelas untuk keberhasilan dari kegiatannya. Sejauh mana keberhasilan diperhitungkan berdasarkan kuota pengunjung yang mencapai target yang sebelumnya direncanakan, tapi tidak ada perhitungan yang pasti dalam pengukurannya. Tidak ada sarana pasti untuk pengunjung memberikan feedback setelah mendatangi kegiatan open house ini.

Sejauh ini feedback dikumpulkan berdasarkan komentar yang terdengar oleh pihak panitia saat kegiatan berlangsung, atau melalui publikasi di media, mengarah kepada pemberitaan yang positif atau negatif. Evaluasi yang dilakukan juga lebih kepada pengukuran kegiatan open house secara teknisnya, bukan pengukuran sejauh apa keberhasilan PTDI membangun kembali brand awareness melalui kegiatan tersebut.

\section{DAFTAR PUSTAKA}

Aaker, D. A. (1995). Building strong brands. New York: The Free Press.

Adisatryo. (2016). Personal interview. 28 Desember 2016.

Apriawan, K. (2016). Personal interview. 29 Desember 2016.

Budiman, I. (2016). Personal interview. 28 Desember 2016.

Cutlip, S. M., Center, A. H., \& Broom, G. M. (2008). Effective public relations (10th ed.). Englewood Cliffs, NJ: Prentice Hall. Jefkins, F. (2004). Public relations. Jakarta: Erlangga.

Matuleviciene, M., \& Stravinskiene, J. (2015). The importance of stakeholders for corporate reputation. Journal Engineering Economics, 26(1), 75-83. https://doi. org/10.5755/j01.ee.26.1.6921.

Nadine. (2017). Personal Interview. 5 Januari 
2017.

Odom, D. G., \& Strout-Dapaz, A. C. (2008). The "Open house," an Effective Library Public relations and Instruction Tool. The Reference Librarian, 32, 67-68, 175-186. https://doi.org/10.1300/J120v32n67_13.

Rossiter, J. R. (2014). “Branding” explained: defining and measuring brand awareness and brand attitude. Journal Of Brand Management, 21 (November), 533-540. https://doi.org/10.1057/bm.2014.33.

Safi'i, S. (2017). Personal Interview. 5 Juli 2017.

Salim, A. (2006). Teori dan paradigma penelitian sosial. Yogyakarta: Tiara
Wacana.

Septiani, G., Sumartias, S., \& Perbawasari, S. (2017). Pembentukan brand awareness warunk indomie upnormal. Jurnal Profesi Humas, 1(2), 124-131.

Soemirat, S., \& Ardianto, E. (2010). Dasardasar public relations. Bandung: Remaja Rosdakarya.

Sugiyono. (2012). Metode penelitian kuantitatif kualitatif dan $r \& d$. Bandung: Alfabeta.

Watson, T. (2012). The evolution of public relations measurement and evaluation. Public Relations Review, 38 (3), 390-398. https://doi.org/10.1016/j. pubrev.2011.12.018. 